\title{
INFLUENCE OF NERVE ON THE FORMATION AND SURVIVAL OF ACETYLCHOLINE RECEPTOR AND CHOLINESTERASE PATCHES ON EMBRYONIC XENOPUS MUSCLE CELLS IN CULTURE ${ }^{1}$
}

\author{
F. MOODY-CORBETT ${ }^{2}$ AND M. W. COHEN $^{3}$ \\ Department of Physiology, McGill University, Montreal, Quebec, Canada II3G 1 Y6
}

Received August 18, 1981; Revised December 30, 1981; Accepted December 30, 1981

\begin{abstract}
Embryonic Xenopus muscle cells grown in culture develop discrete patches of high acetylcholine receptor (AChR) density. By following identified muscle cells after staining with fluorescent $\alpha$ bungarotoxin, we have found that many of these $\mathrm{AChR}$ patches survive in a fixed position for several days. For AChR patches on the lower surface of the cell (the surface apposed to the culture dish), more than $60 \%$ of those which were followed beginning on day 2 survived for a further 4 days. The survival rate was greater when patches were followed from day 3 or later and was almost as high for AChR patches on the upper surface. New AChR patches also formed on all of the muscle cells. When muscle cells were cultured together with spinal cord cells, nerve-muscle contacts developed with a characteristic localization of AChRs along the path of contact. AChR patches did not form elsewhere on these contacted cells. Nerve-contacted muscle cells examined 2 to 3 days after adding spinal cord cells to established (2- to 5-day-old) muscle cultures also exhibited a marked reduction of AChR patches away from the site of contact. This reduction was not due to the nerve having contacted pre-existing $\mathrm{AChR}$ patches. Rather, the findings indicate that contact by an appropriate nerve inhibits the formation of AChR patches elsewhere on the contacted muscle cells and reduces the survival of pre-existing AChR patches. Nerve contact also inhibited the formation of cholinesterase $(\mathrm{ChE})$ patches remote from the site of contact and appeared to cause some reduction in the survival of pre-existing $\mathrm{ChE}$ patches. Spontaneous twitching was not observed in these experiments, thereby indicating that the remote effects of nerve contact were not mediated by muscle action potentials or contraction. Such remote influences of the nerve may play a role in determining the pattern of innervation on individual muscle cells.
\end{abstract}

Innervation has local as well as remote effects on the surface properties of skeletal muscle fibers. Locally, innervation triggers the development of a high density of acetylcholine receptors (AChRs), the accumulation of cholinesterase (ChE), and the formation of characteristic surface invaginations (Aitken, 1950; Miledi, 1962; Couteaux, 1963; Fex et al., 1966; Anderson and Cohen, 1977;

\footnotetext{
'This work was supported by the Medical Research Council of Canada. Personal support of F. M. -C. from the Faculty of Medicine, McGill University and to M. W. C. from Le Conseil de la Recherche en Santé du Québec is also gratefully acknowledged. We thank Dr. R. I. Birks for the use of his microscope facilities and for continued interest in this work and Dr. D. Davey for helpful suggestions. Mr. C. Cantin provided expert technical assistance.

${ }^{2}$ Present address: Department of Anatomy, Harvard Medical School, Boston, MA 02115 .

${ }^{3}$ To whom correspondence should be addressed at Department of Physiology, McGill University, 3655 Drummond Street, Montreal, Quebec, Canada H3G 1 Y 6.
}

Anderson et al., 1977; Frank and Fischbach, 1979; Lomo and Slater, 1980a, b; Rubin et al., 1980). Additional local effects of innervation also may include a decrease in the rate of degradation of the synaptic AChRs (Berg and Hall, 1975; Chang and Huang, 1975; Burden, 1977a, b; Steinbach et al., 1979; Reiness and Weinberg, 1981), a decrease in the mean open time of the synaptic AChR channels (Brenner and Sakmann, 1978; Sakmann and Brenner, 1978; Fischbach and Schuetze, 1980; but see also Schuetze, 1980; Kullberg et al., 1981), the development of synapse-specific basal lamina (Weinberg et al., 1981), and enhanced electrogenic sodium pump activity (Betz et al., 1980). Remote from the site of innervation, the density of $\mathrm{AChRs}$ decreases to a very low value (Miledi, 1960; Diamond and Miledi, 1962; Bevan and Steinbach, 1977; Burden, 1977b) and the muscle cell becomes refractory to further innervation (Elsberg, 1917; Aitken, 1950; Miledi, 1962; Fex et al., 1966). These remote effects of innervation appear to be mediated, at least in 
part, by the muscle activity associated with neuromuscular transmission (Lomo and Rosenthal, 1972; Jansen et al., 1973; Lomo and Slater, 1978), although additional neural factors also may play a role (Miledi, 1960; Gilliatt et al., 1978; Antony and Tonge, 1980; Eldridge et al., 1981). Muscle activity reduces the density of extrasynaptic AChRs by inhibiting the replacement of degraded AChRs (Hogan et al., 1976; Hall and Reiness, 1977; Linden and Fambrough, 1979).

Studies on cultures of nerve and muscle derived from Xenopus embryos have suggested that innervation may have additional remote effects. Noninnervated muscle cells in these cultures develop discrete sites of high AChR density which occupy about 2 to $3 \%$ of the cell surface (Anderson et al., 1977; Moody-Corbett and Cohen, 1981). By contrast, many of the nerve-contacted muscle cells exhibit a high density of AChRs along the path of contact but have no AChR patches elsewhere on their surface (Anderson et al., 1977; Cohen and Weldon, 1980). These findings suggest that contact by nerve can prevent the formation of $\mathrm{AChR}$ patches elsewhere on the muscle cell. Experiments in which nerve was added to 2- to 3-day-old muscle cultures have suggested further that nerve contact can cause a loss of pre-existing AChR patches (Anderson and Cohen, 1977; Anderson et al., 1977). Similar remote effects of nerve contact also may occur in cultures of embryonic chick nerve and muscle (Frank and Fischbach, 1979) and in vivo (Braithwaite and Harris, 1979; Jacob and Lentz, 1979; Weinberg et al., 1981). In cultures derived from Xenopus embryos, the remote influence of nerve contact appears to occur even when the cultures are grown in the presence of agents which block muscle activity (Anderson and Cohen, 1977; Anderson et al., 1977).

The loss of AChR patches at sites remote from the nerve-muscle contact raises the question of the stability of the patches. It could be that, even on noncontacted muscle cells, AChR patches normally survive for only 1 or 2 days, while new ones form elsewhere (see Anderson and Cohen, 1977). In that case, the nerve might act by preventing the formation of new patches away from sites of nerve-muscle contact. Alternatively, the AChR patches on noncontacted muscle cells may normally survive for several days and the nerve contact might act by reducing their survival. To distinguish between these possibilities, we have investigated the survival of $\mathrm{AChR}$ patches on embryonic Xenopus muscle cells cultured with and without nerve. Our findings indicate that contact by nerve not only prevents the formation of receptor patches at sites remote from the path of nerve-muscle contact but also reduces the survival of pre-existing receptor patches. Cholinesterase patches, which also develop on these muscle cells (Moody-Corbett and Cohen, 1981; Weldon et al., 1981), appear to be influenced by the nerve in a similar fashion but to a lesser extent.

A brief account of part of this study has been reported previously (Moody-Corbett and Cohen, 1980).

\section{Materials and Methods}

The preparation of the muscle cultures has been described previously (Anderson et al., 1977; Moody-Corbett and Cohen, 1981). Briefly, myotomes of 1-day-old (stage
21 to 24, Nieuwkoop and Faber, 1967) Xenopus laevis embryos were isolated with the aid of collagenase and dissociated into single cells by treatment with a calcium/ magnesium-free solution of trypsin and EDTA. The muscle cells were plated on collagen-coated coverslips in a medium containing $67 \%$ L15 and $5 \%$ dialyzed horse serum. One day later, the plating medium was replaced with a maintenance medium containing $67 \% \mathrm{~L} 15$ and 0.2 $\mu \mathrm{g} / \mathrm{ml}$ of Holmes' $\alpha$-1-protein.

Mixed cultures of nerve and muscle were prepared by adding spinal cord cells to the culture chamber at the same time as the muscle cells or up to 5 days after plating the muscle cells. For this purpose, spinal cords from stage 21 to 28 embryos were isolated with the aid of collagenase and then carefully cut into small lengths and dissociated in a calcium/magnesium-free solution for approximately $1 \mathrm{hr}$. Mixed cultures were maintained in maintenance medium as described above or in a maintenance medium that also contained a low concentration of dialyzed horse serum $(0.5 \%)$. Muscle and nerve cells sometimes were obtained from embryos which had been kept in an incubator at 16 to $18^{\circ} \mathrm{C}$ for 1 to 2 days.

AChRs on living muscle cells were stained with tetramethylrhodamine $\alpha$-bungarotoxin (Anderson et al., 1977; Cohen and Weldon, 1980). A low concentration of the fluorescent toxin $(\sim 0.1 \mu \mathrm{g} / \mathrm{ml})$ was kept in the culture chamber thereafter so that any newly inserted receptors also would be stained. With this procedure, AChR patches remained bright for several days. When necessary, the cultures were restained. The formation and survival of AChR accumulations thus could be followed on identified muscle cells. When the influence of nerve was to be examined on pre-existing AChR patches, the cultures were stained with the fluorescent toxin immediately before adding nerve and were maintained thereafter in a low concentration of toxin as described above. Two to 3 days later, the cultures were examined alive or after fixation and ChE histochemistry (see below).

Cultures which were to be examined for $\mathrm{ChE}$ stain were first fixed with $1.5 \%$ glutaraldehyde in $0.1 \mathrm{M}$ phosphate buffer (pH 7.3) for $1 \mathrm{hr}$ or with a mixture of $0.15 \%$ glutaraldehyde and $2 \%$ formaldehyde in $67 \%$ L15 for 20 to $45 \mathrm{~min}$. When $\mathrm{AChR}$ and $\mathrm{ChE}$ stains were to be examined on the same cells, the cultures were first stained or restained with the fluorescent toxin and then fixed with the mixture of glutaraldehyde and formaldehyde (Moody-Corbett and Cohen, 1981). Following fixation, the cultures were rinsed with frog Ringer solution and stained for ChE (Karnovsky, 1964; Moody-Corbett and Cohen, 1981). When the initial fixation times were short, the cultures were postfixed overnight at $4^{\circ} \mathrm{C}$ with $10 \%$ formaldehyde in $0.1 \mathrm{~m}$ HEPES buffer, $\mathrm{pH}$ 7.4. The fixed cultures were rinsed, cleared in glycerol, and viewed with phase contrast and fluorescence optics using $\times 6.3$ oculars and $\times 63 / 1.4$ or $\times 100 / 1.3$ objectives.

\section{Results}

\section{Stability of sites of high acetylcholine receptor density}

Muscle cells cultured without nerve. Muscle cells chosen on the first 4 days in culture were followed on subsequent days until cell death. On 22 cells (six cul- 
tures), all of the AChR patches on the cells were examined, and on 6 other cells (two cultures), only a part of the cell was followed.

A portion of a typical sequence is shown in Figure 1. In this example, all of the AChR patches were on the lower surface of the muscle cell, that is on the surface apposed to the culture dish. On the 3rd day (Fig. 1A) in culture, 1 faint and 2 bright AChR patches were present. By day 5 (Fig. $1 B$ ), a new AChR patch had appeared, and by day 8 (Fig. $1 C$ ), 2 additional $A C h R$ patches were present. During this period, as the cell continued to grow, all of the original patches were maintained in their same position relative to stationary points on the culture dish, and their size and shape also remained essentially un-
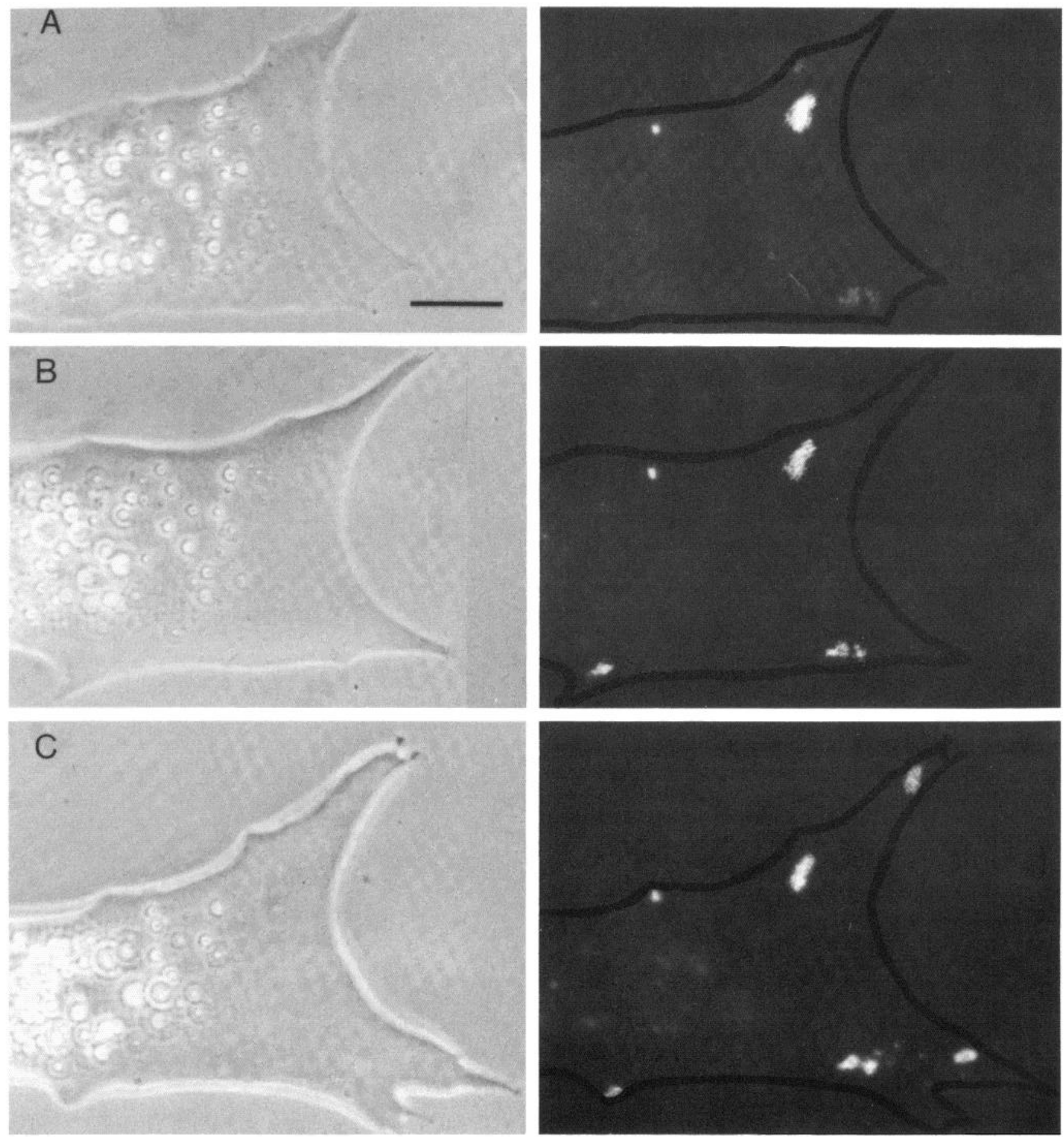

Figure 1. Survival and formation of AChR patches in a nerve-free culture. The panels on the left show phase contrast views and the panels on the right show the corresponding fluorescence views. $A$, On day $3,3 \mathrm{AChR}$ patches were visible on the lower surface. $B$, On day 5 , the 3 original patches plus 1 new AChR patch were present. $C$, On day 8,2 new AChR patches were seen in a region where cell growth had occurred. Note that the original receptor patches remained in a fixed position despite changes in the shape of the muscle cell. Calibration bar, $20 \mu \mathrm{m}$. 

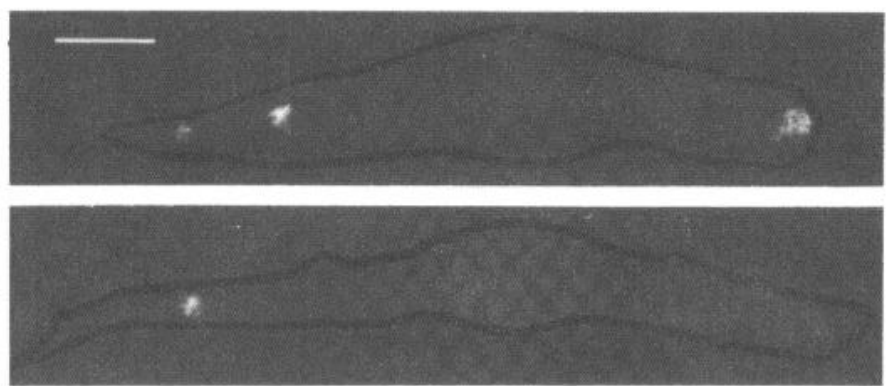

Figure 2. Survival and loss of AChR patches on the lower surface of a muscle cell in a nerve-free culture. The cell, outlined in black, had $3 \mathrm{AChR}$ patches on day 3 (top). By day 5 , only 1 of the original patches remained (bottom). Calibration bar, 20 $\mu \mathrm{m}$.

changed. These features, a fixed position (see below) and an unchanging size and shape, of surviving AChR patches were common on virtually all cells examined and allowed for easy identification of individual $\mathrm{AChR}$ patches day after day. However, not all receptor patches survived for several days. For example, the cell in Figure 2 had 3 lower surface AChR patches present on day 3, but by day 5 , only 1 of the original patches was still present. Restaining did not reveal any more patches.

By using such sequences, the survival of the AChR patches was determined. The results for patches on the lower surface of the cells are summarized in Figure $3 A$. Two main points are apparent. Firstly, many of the AChR patches have a relatively long lifetime. For example, $50 \%$ of the AChR patches which were present on day 1 were still present 4 days later. Secondly, as the age of the culture increased, the percentage of patches which survived for 4 additional days also increased. Thus, the corresponding survival rate was $61 \%$ for patches on day 2 and $89 \%$ for patches on day 5 .

The relatively long survival times were not restricted to $\mathrm{AChR}$ patches found on the lower surface. Patches on the upper surface (not in contact with a solid substrate) also survived for several days (Fig. 4). Fewer upper surface patches were followed, but their survival generally appeared to follow the same pattern as lower surface patches. On the first 2 days in culture, only 4 upper surface patches were seen on the cells that were being followed and 3 of these survived for a further 4 days. On days 3 to 5 , more upper surface patches were present and the proportion which survived for a further 4 days increased from $43 \%$ on day 3 to $63 \%$ on day 5 (Fig. $3 B$ ). Thus, AChR patches on the upper surface, like those on the lower surface, can have a lifetime of several days and the probability of their continued survival tends to increase with the age of the culture.

In the above experiments, whenever two fixed points on the culture dish could be identified in the same photographic field as an AChR patch, the position of the patch relative to these points was evaluated for the duration of patch survival. Such measurements were made on 69 receptor patches on the lower surface and 63 of these remained in the same position over a period of 2 to 13 days. Similar measurements were made on 12 AChR patches on the upper surface and 11 of these remained in the same position for 3 to 10 days. Thus, most receptor patches, even when they are not apposed to a solid substrate, remain in a fixed position relative to stationary points on the culture dish. In the few other cases, the patches remained within $5 \mu \mathrm{m}$ of their original position.

In addition to patch survival, we also documented the number of new AChR patches which formed on the cells that were followed. The formation of new patches occurred throughout the range of ages examined in this study and tended to decrease as the age of the culture increased (Fig. 5). Between days 2 and 6 , all of the muscle cells that were followed acquired at least 1 new patch. On the lower surface, patches formed very close to the periphery of the cell (also see Anderson et al., 1977), and in about $30 \%$ of the cases, they formed in regions where the muscle cell had grown during the previous day. Measurements of the shortest distance between the patch and the cell periphery gave a value of $3.2 \pm 0.4 \mu \mathrm{m}$

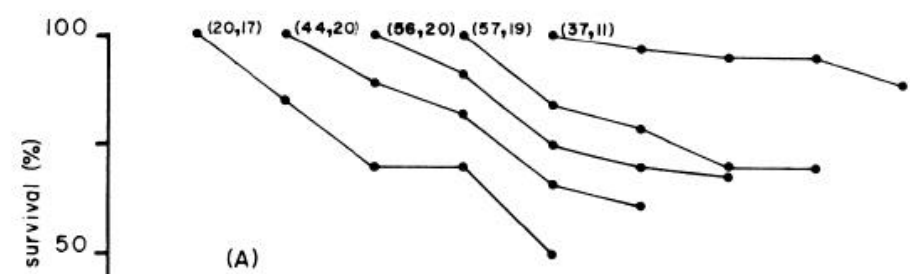

lower surfoce
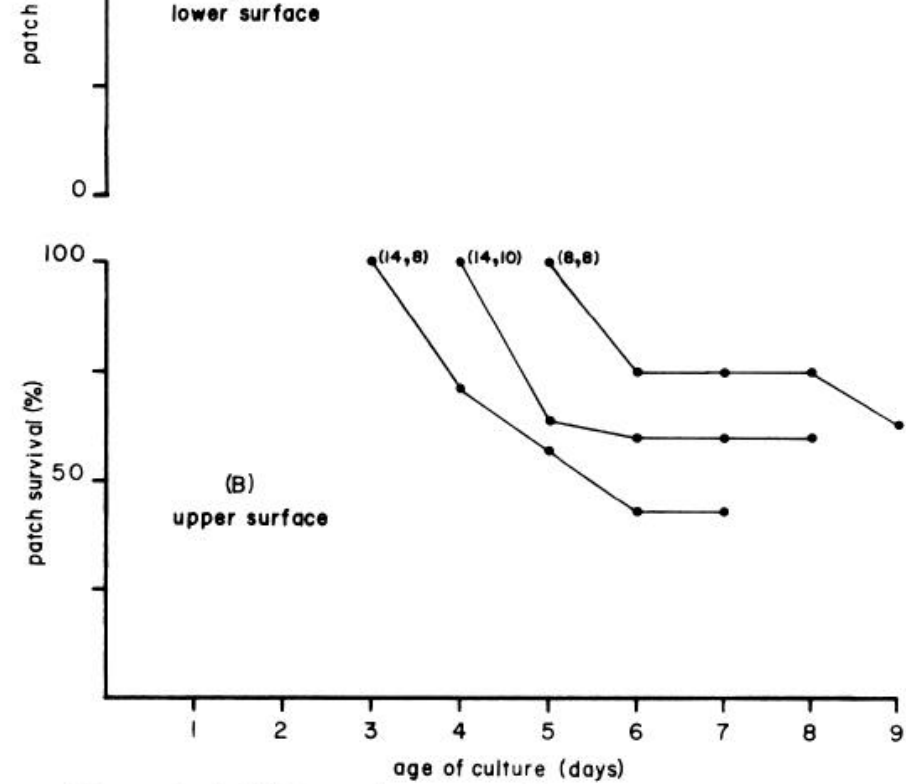

Figure 3. AChR patches were identified on selected cells during the first 5 days in culture, and for each day, the percentage of patches which survived 4 additional days was determined. Each set of points joined by a line beginning at $100 \%$ indicates the percentage of identified patches which were present on the 4 successive days. Only data from muscle cells which survived throughout the 4-day period are included. $A$, The survival of patches on the lower surface, next to the floor of the culture dish. $B$, The survival of patches on the upper surface, free of contact with a solid substrate. The numbers in parentheses refer to the number of cells and the number of patches, respectively. Note that the lines become less steep with increasing age, indicating that the continued survival of the $\mathrm{AChR}$ patches increased with the age of the culture. Note also that about $50 \%$ of the patches in the youngest cultures survived for 4 additional days. 

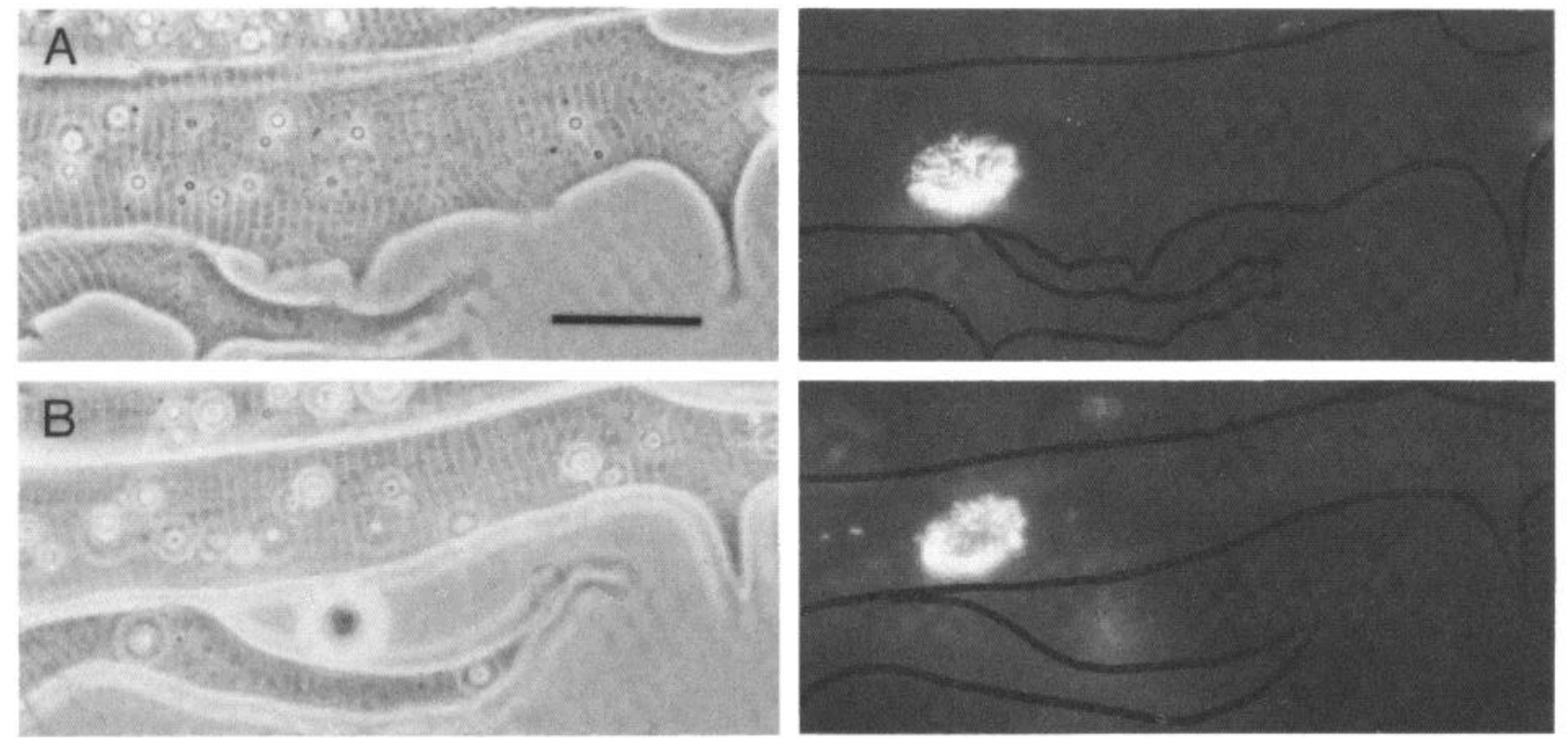

Figure 4. Survival of an AChR patch on the upper surface of a muscle cell in a nerve-free culture. The receptor patch survived and remained essentially unchanged from day 4 (top) to day 10 (bottom). Left, Phase contrast views; right, corresponding fluorescence views. Calibration bar, $20 \mu \mathrm{m}$.

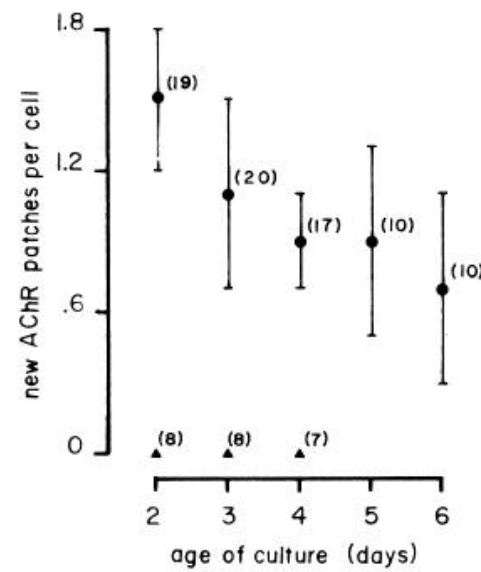

Figure 5. The number of newly formed AChR patches per cell on noncontacted muscle cells $(\Theta)$ and on nerve-contacted muscle cells which had AChR localization along the path of contact $(\boldsymbol{\Delta})$. In order to avoid including unhealthy or dying cells, the data for each day are based on muscle cells which survived for at least 4 more days. The number of cells is shown in parentheses. The bars indicate $1 \mathrm{SE}$. Note that AChR patches did not form on the nerve-contacted cells.

(mean $\pm \mathrm{SE}, n=98$ ). By contrast, upper surface patches tended to form in more central regions of the cell and their shortest distance from the cell periphery was $9.3 \pm$ $1.6 \mu \mathrm{m}(n=24)$.

From these results, it is possible to summarize three main points regarding the formation and survival of AChR patches on these muscle cells in culture. Firstly, many of the AChR patches survive for several days and the probability of continued patch survival tends to increase with the age of the culture. Secondly, almost all of the AChR patches which do survive remain in fixed positions relative to stationary points on the culture dish and this is the case even for patches which are not apposed to a solid substrate. Finally, new AChR patches continue to form for several days at a rate which tends to decline slowly with the age of the culture.

Nerve-contacted muscle cells. Eleven muscle cells (two cultures) which were contacted by nerve on the 1st day in culture were followed for up to 8 days. All of these muscle cells had AChR stain associated with the path of the nerve contact on day 1 . The survival of this stain and the formation and survival of receptor patches elsewhere on the cell were determined by examining the cultures at intervals of 1 to 2 days.

Before describing the results of these experiments, it is important to clarify our use of the term "AChR patch." Cultured Xenopus muscle cells exhibit two main patterns of AChR localization (Anderson et al., 1977). At nervemuscle contacts, the receptor accumulations generally occur as narrow bands oriented in the same direction as the nerve (see Fig. 6A). On the other hand, receptor accumulations which are not located at sites of nervemuscle contact can be broader and sometimes exhibit an intricate substructure (see Figs. 2 and 4; see also Anderson et al., 1977; Moody-Corbett and Cohen, 1981). We do not refer to the contact-associated AChR accumulations as AChR patches. Rather, we use the term AChR patch to refer only to the receptor accumulations which are seen on noncontacted muscle cells and on nerve-contacted muscle cells away from the site of contact.

Part of a sequence from a representative nerve-contacted muscle cell is shown in Figure 6. On the 1st day in culture, the nerve coursed across the lower surface of the cell and along both edges of the cell (Fig. 6A). At this time, AChR stain was seen only along the path of contact. Between the 1st and 2nd day, the nerve process retracted, but even on day 5 (Fig. $6 B$ ), much of the original staining pattern was still apparent. Also seen for the first time on day 5 were AChR patches at one end where the muscle cell had grown. On day 8 (Fig. $6 C$ ), the staining pattern was much the same except that additional AChR 

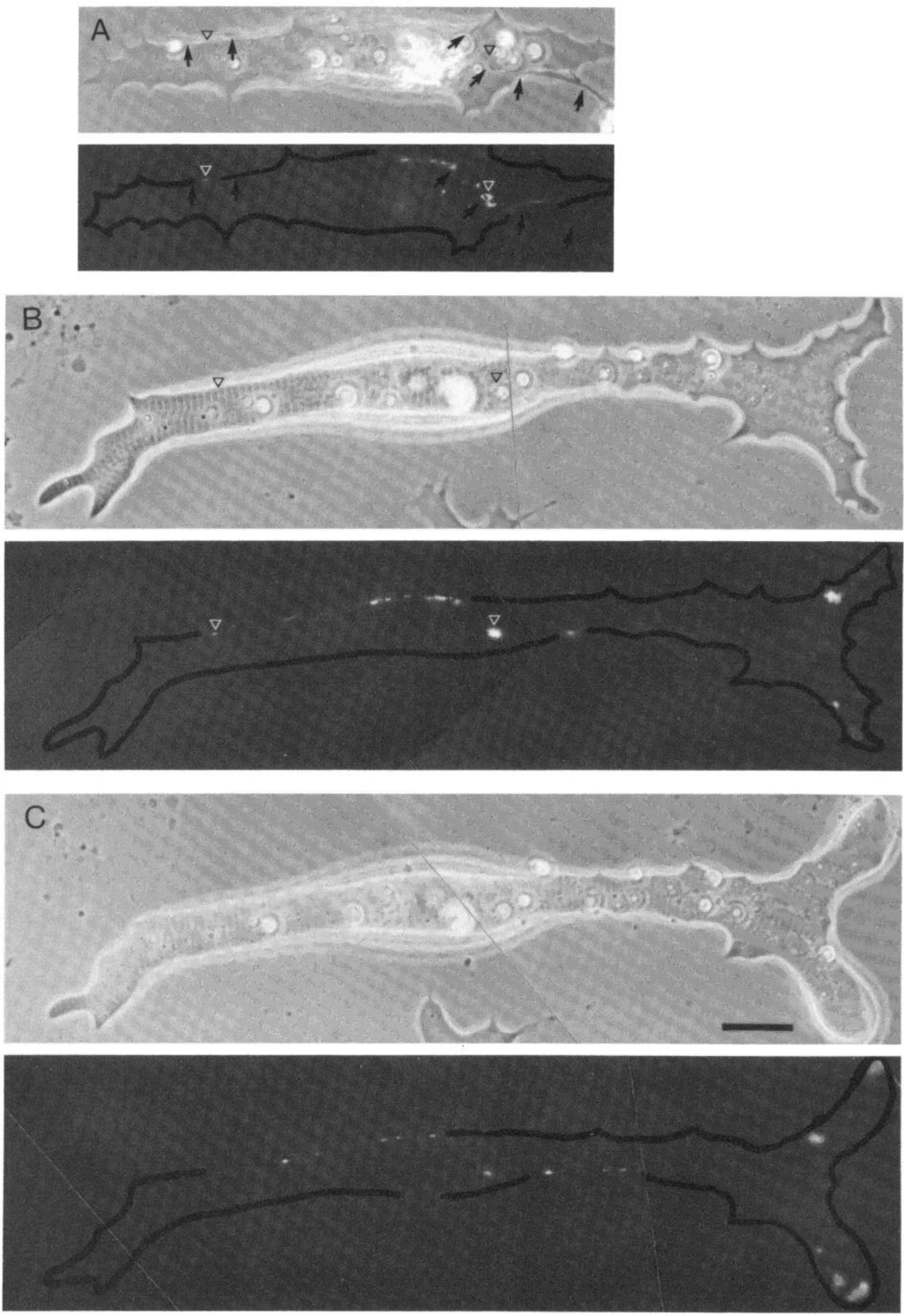


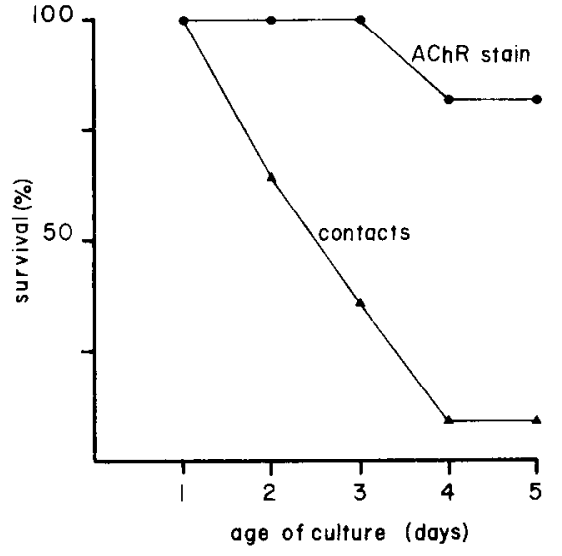

Figure 7. The survival of nerve contacts $(\Delta)$ and contactassociated AChR stain (O) on 11 muscle cells that were contacted by nerve on the 1st day in culture. All of these muscle cells had AChR stain along the path of contact. Survival is expressed as the percentage of muscle cells at which the nerve contacts or portions of the contact-associated stain were present on each successive day.

patches were now apparent and there was less receptor stain along the original path of nerve-muscle contact.

The main changes seen in the above sequence were common to the other nerve-contacted cells that were studied and may be summarized as follows. Firstly, the nerve contacts were not stable. By day 3 , most nerves had retracted, and by day 4 , only 1 muscle cell was still contacted by nerve (Fig. 7). Secondly, in spite of the transitory nature of the contact, portions of the $\mathrm{AChR}$ accumulations seen along the original path of contact were maintained for several days. This survival, as plotted in Figure 7, appears better than the survival of AChR patches on noncontacted muscle cells (see Fig. 3). However, it should be borne in mind that, at nerve-muscle contacts, some portions of the AChR accumulation survived, whereas other portions along the same contact did not (see Fig. 6). By comparison, the individual AChR patches on noncontacted muscle cells almost always remained unaltered during their survival. For this reason, the data in Figure 7 are not strictly comparable to those in Figure 3. Nonetheless, the results do indicate that at least portions of the receptor accumulations at nervemuscle contacts survive for several days even in cases where the nerve retracts.

A third main observation on nerve-contacted muscle cells concerns the survival and formation of AChR patches elsewhere on the cell. On day 1 , such patches were seen on only 3 of the 11 contacted cells, and by day 3 , all of these patches had disappeared. Furthermore, in contrast to noncontacted muscle cells, there was no for- mation of new receptor patches away from the original path of nerve-muscle contact during the first 4 days in culture even in cases where the nerve had retracted (Fig. $5)$. The earliest appearance of such patches was on day 5 (see Fig. 6), 4 days after the nerve was last seen contacting the cell. These results indicate that contact by an appropriate nerve inhibits the formation of new AChR patches elsewhere on the cell and that this effect persists for a few days even after the nerve retracts.

\section{Influence of nerve on pre-existing receptor patches}

In the experiment described above, nerve and muscle were plated together so that the influence of the nerve on the formation of new receptor patches could be examined. For the experiments described in this section, the nerve was added to established muscle cultures in order to examine its influence on the survival of preexisting AChR patches. In this regard, it should be recalled that, when embryonic Xenopus muscle cells are cultured without nerve, about $95 \%$ of the muscle cells have receptor patches from day 2 on (Anderson et al., 1977; Cohen and Weldon, 1980; Moody-Corbett and Cohen, 1981). Accordingly, in the present experiments, muscle cultures were grown for 2 to 3 days or for 5 days, by which age most of the AChR patches are destined to survive for several more days (see Fig. 3). Nerve was then added and the cultures were examined 2 to 3 days later. The frequency of occurrence of $\mathrm{AChR}$ patches was assessed on noncontacted muscle cells and on nervecontacted muscle cells which had receptor stain along the path of contact. To control for the possible effects of neuronal conditioning of the culture medium, the nervecontacted muscle cells were always compared with noncontacted muscle cells in the same culture.

The results are summarized in Figure 8. In contrast to the noncontacted cells (open columns), the nerve-contacted cells (solid columns) showed a large reduction not only in the number of AChR patches per cell (Fig. $8 B$ ) but also in the percentage of cells having any AChR patches at all (Fig. 8A). This was the case for AChR patches on both the lower surface and the upper surface. Essentially similar results were obtained whether the cultures were examined alive (Table I) or after fixation and ChE histochemistry (Fig. 8). Particularly noteworthy is the finding that the occurrence of receptor patches on nerve-contacted cells was reduced markedly even in the case where the nerve was added to 5-day-old muscle cultures. In the absence of nerve, most of the AChR patches in 5-day muscle cultures are very stable (see Fig. 3). Taken together, these findings indicate that contact by an appropriate nerve can eliminate AChR patches which would otherwise survive for several days.

Figure 6. Sequence showing the survival of a nerve contact and the formation and survival of AChR accumulations on the contacted muscle cell. $A$, On day 1 , the nerve could be seen contacting the muscle cell along one edge, passing across the lower surface, and extending along the other edge (arrows). AChR stain was localized along portions of the contact. The nerve contact was no longer present on day 2 (not shown). However, on day $5(B)$, the original staining pattern was still apparent. For example, the two triangles in $A$ and $B$ point to sites of $\mathrm{AChR}$ stain which remained in the same position between day 1 and day 5 . Also, on day 5 for first time, new AChR patches had appeared on the lower surface at one end of the cell. $C$, By the 8th day in culture, there was less stain along the original path of the nerve and additional AChR patches had appeared on the lower surface. In each panel, the upper segment shows the phase contrast view, while the lower segment shows the corresponding fluorescence view. Calibration bar, $20 \mu \mathrm{m}$. 


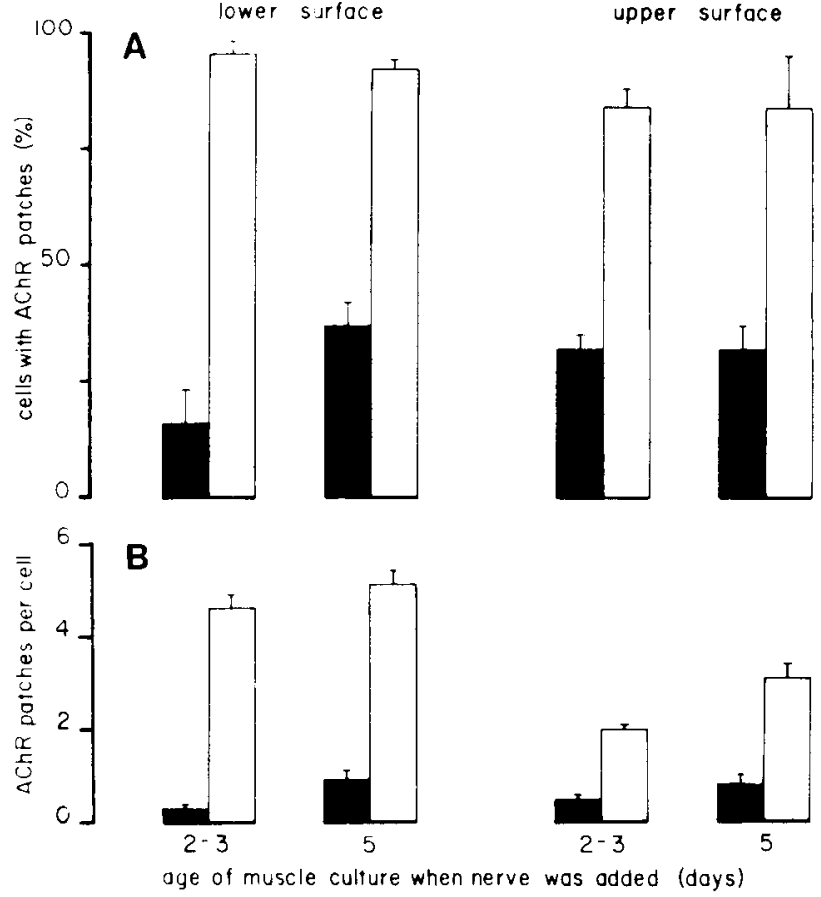

Figure 8. Occurrence of AChR patches on the lower surface and upper surface of nerve-contacted (solid columns) and noncontacted muscle cells (open columns). The nerve-contacted muscle cells had AChR localization along the path of contact. Nerve was added to muscle cultures on days 2 to 3 or on day 5 and the cultures were examined 2 to 3 days later (after fixation and $\mathrm{ChE}$ staining). Eighty-two nerve-contacted and 160 noncontacted muscle cells were examined in four cultures in the day 2 to 3 group, and 79 nerve-contacted and 120 noncontacted muscle cells were examined in three cultures in the day 5 group. The bars indicate SE. $A$, Percentage of cells with patches; $B$, number of patches per cell. Note the decreased incidence of $\mathrm{AChR}$ patches on the nerve-contacted muscle cells.

$\Lambda \mathrm{n}$ alternative explanation for the lack or total absence of AChR patches away from the site of contact on nervecontacted muscle cells is that the pre-existing receptor patches were contacted by the nerve. However, two additional findings make this explanation untenable. As noted above, the AChR accumulations which are associated with nerve-muscle contacts typically appear as narrow bands oriented in the same direction as the contact, whereas the receptor patches on noncontacted cells are often broader. Examination of $\mathrm{AChR}$ accumulations at nerve-muscle contacts in the present experiments revealed that in only $3 \%$ of the cases $(n=181)$ was the contact associated with a receptor accumulation which was not oriented in the same direction as the nerve. Secondly, in 157 cases, the contacts and associated $\mathrm{AChR}$ accumulations were restricted entirely to the edge and/or upper surface of the muscle cells, yet $75 \%$ of these cells had no receptor patches at all on their lower surface which was not contacted by nerve. By contrast, the great majority of noncontacted muscle cells do have AChR patches on their lower surface (Fig. 8; Table I; see also Moody-Corbett and Cohen, 1981). It is apparent therefore that contact by an appropriate nerve reduces the survival of pre-existing AChR patches elsewhere on the muscle cell.

During the course of examining living cultures in the above experiments, spontaneous twitching of the nervecontacted muscle cells was never observed. This is not surprising in view of the fact that the cultures were stained with fluorescent $\alpha$-bungarotoxin just before the addition of nerve and were maintained thereafter in a low concentration of the fluorescent toxin (see "Materials and Methods"). It therefore seems likely that the effect of the nerve on the survival of receptor patches occurred in the absence of muscle action potentials or contraction.

An attempt was made to examine this effect further by adding nerve such that it would contact previously identified muscle cells. Success was achieved in only one case which is shown in Figure 9. Just before the addition of nerve to a 5-day-old muscle culture, two closely apposed muscle cells had several AChR patches on their lower surface (Fig. 9A). When viewed again 2 days later, a nerve process was seen extending from a small cluster of spinal cord cells and coursing along the 2 muscle cells in the region of their apposition. At this time, some of the original AChR patches were no longer visible and some others were very faint (Fig. 9B). On the next day, the culture was restained and examined again. The nerve process had retracted, but receptor stain was now visible along the former path of contact (Fig. 9C). In addition, none of the original $\mathrm{AChR}$ patches on either muscle cell was present. Fifteen other muscle cells were followed in the same culture but were not contacted by nerve. These cells had a total of $71 \mathrm{AChR}$ patches on day 5 and $83 \%$ of these patches were still present on day 8 . Thus, the complete disappearance of $\mathrm{AChR}$ patches in the example of Figure 9 reinforces the conclusion that contact by an appropriate nerve not only causes a localization of receptors along the contact but also greatly reduces the survival of receptor patches elsewhere on the cells. The example also indicates that these effects of the nerve can occur even when the contact is transient.

\section{Influence of nerve on the occurrence of cholinesterase patches}

When Xenopus muscle cells are cultured in the absence of nerve, they develop surface patches of cholinesterase

TABLE I

Occurrence of AChR patches (away from sites of contact) on nervecontacted and noncontacted muscle cells prior to fixation and ChE histochemistry

The nerve-contacted cells had AChR stain localized along the path of contact. Two living cultures were examined at each age 2 to 3 days after adding nerve. The numbers in parentheses indicate the numbers of cells examined.

\begin{tabular}{|c|c|c|c|}
\hline $\begin{array}{c}\text { Age of Muscle } \\
\text { Culture when } \\
\text { Nerve Was } \\
\text { Added }\end{array}$ & $\begin{array}{l}\text { Category of Muscle } \\
\text { Cell Examined }\end{array}$ & $\begin{array}{l}\text { Cells with } \\
\text { Patches on } \\
\text { Lower Surface }\end{array}$ & $\begin{array}{c}\text { Cells with } \\
\text { Patches on } \\
\text { Upper Surface }\end{array}$ \\
\hline days & & \multicolumn{2}{|c|}{$\pi$} \\
\hline \multirow[t]{2}{*}{$2-3$} & $\begin{array}{c}\text { Nerve-contacted } \\
\text { (45) }\end{array}$ & 33 & 49 \\
\hline & $\begin{array}{c}\text { Noncontacted } \\
(80)\end{array}$ & 96 & 70 \\
\hline \multirow[t]{2}{*}{5} & $\begin{array}{c}\text { Nerve-contacted } \\
(76)\end{array}$ & 26 & 47 \\
\hline & $\begin{array}{c}\text { Noncontacted } \\
(80)\end{array}$ & 84 & 80 \\
\hline
\end{tabular}



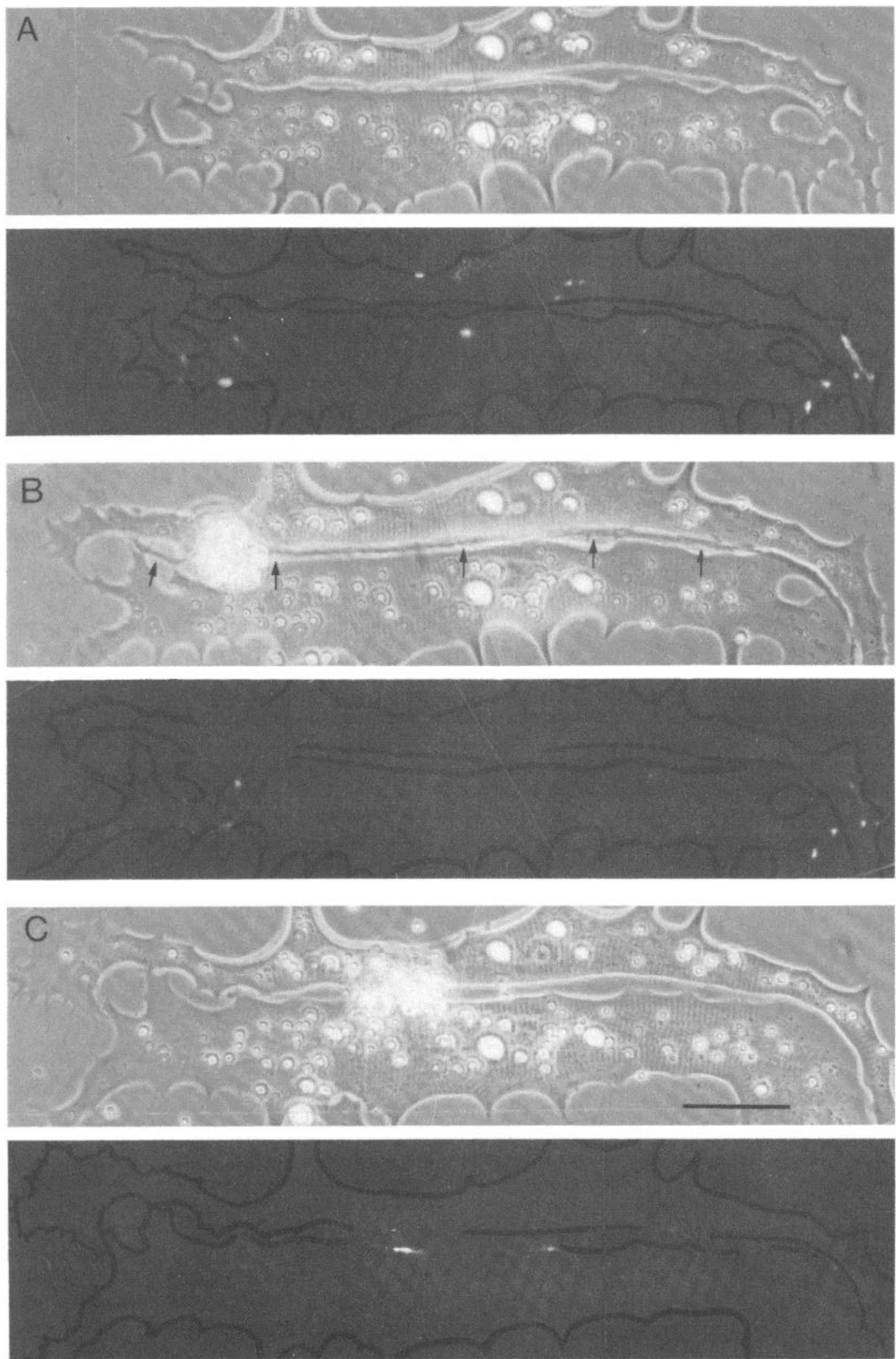

Figure 9. Loss of $\mathrm{AChR}$ patches on identified muscle cells contacted by nerve. $A$, Two closely apposed muscle cells were located on day 5 immediately before spinal cord cells were added to the culture. At this time, several AChR patches were apparent on the lower surface. $B$, Two days later on day 7 , a nerve process was seen extending between the 2 cells (arrows) and only some of the original patches were present. $C$, On day 8 , the culture was restained and examined again. By this time, the nerve had retracted. AChR stain was apparent along the edge of both muscle cells where the nerve had been, but none of the original patches was present. In each panel, the upper segment shows the phase contrast view, while the lower segment shows the corresponding fluorescence view. The calibration bar is $40 \mu \mathrm{m}$ and applies to the entire figure. 
(ChE) which are similar in appearance to AChR patches (Moody-Corbett and Cohen, 1981). These ChE patches are seen on virtually all muscle cells from day 2 on and show a high frequency of co-localization with receptor patches (Moody-Corbett and Cohen, 1981). Furthermore, when nerve is cultured together with muscle, many of the nerve-contacted muscle cells exhibit ChE localization along the path of contact, and in most of these cases, there is also receptor localization along the path of contact (Moody-Corbett et al., 1982). As described for the $\mathrm{AChR}$ stain, the $\mathrm{ChE}$ reaction product associated with sites of nerve-muscle contact is readily distinguished from the ChE patches seen away from nerve-muscle contacts.

To examine the influence of the nerve on the formation of ChE patches, nerve was plated at the same time as muscle or within $24 \mathrm{hr}$ after plating muscle. After 3 to 5 days, the cultures were stained for $\mathrm{ChE}$, and the occurrence of $\mathrm{ChE}$ patches was examined on noncontacted muscle cells and on nerve-contacted muscle cells which had ChE localized along the path of contact. As summarized in Table II, ChE patches were seen much less frequently on nerve-contacted cells than on the noncontacted cells. The relative lack of $\mathrm{ChE}$ patches on the lower surface of nerve-contacted cells is particularly noteworthy because, on 131 of the 153 nerve-contacted cells that were examined, the contacts and their associated ChE were restricted to the edge and/or upper surface. Therefore, the results indicate that contact by an appropriate nerve inhibits the formation of $\mathrm{ChE}$ patches elsewhere on the muscle cell.

To determine whether the nerve also might influence the survival of pre-existing ChE patches, we examined the same cultures and cells that were used in determining the neural influence on survival of receptor patches (see Fig. 8 and previous section). The results are summarized in Figure 10. When the muscle cells were evaluated in terms of whether they had ChE patches (Fig. 10A), there was no significant difference between the nerve-contacted cells (solid columns) and the noncontacted cells (open columns). However, when evaluated in terms of the number of $\mathrm{ChE}$ patches per cell, the nerve-contacted muscle cells were found to have significantly fewer ChE patches on their lower surface than the noncontacted cells (Fig. 10B). This was the case whether the nerve was added to 2- to 3-day-old muscle cultures or to 5-day-old muscle cultures. On the other hand, nerve contact did not significantly alter the number of ChE patches on the upper surface in these cultures (Fig. 10B).

\section{TABLE II}

Occurrence of ChE patches (away from sites of contact) on nervecontacted and noncontacted muscle cells in five cultures

Means \pm SE are based on examination of 40 to 60 noncontacted muscle cells and 22 to 40 nerve-contacted muscle cells in each culture. Nerve and muscle were grown together for 3 to 5 days. The nervecontacted cells had $\mathrm{ChE}$ localized along the path of contact.

\begin{tabular}{ccc}
\hline $\begin{array}{c}\text { Category of Muscle Cell } \\
\text { Examined }\end{array}$ & $\begin{array}{c}\text { Cells with Lower } \\
\text { Surface Patches }\end{array}$ & $\begin{array}{c}\text { Cells with Upper } \\
\text { Surface Patches }\end{array}$ \\
\hline & & $\%$ \\
Nerve-contacted & $30.5 \pm 9.9$ & $16.0 \pm 7.4$ \\
Noncontacted & $91.3 \pm 1.1$ & $50.5 \pm 14.5$ \\
\hline
\end{tabular}

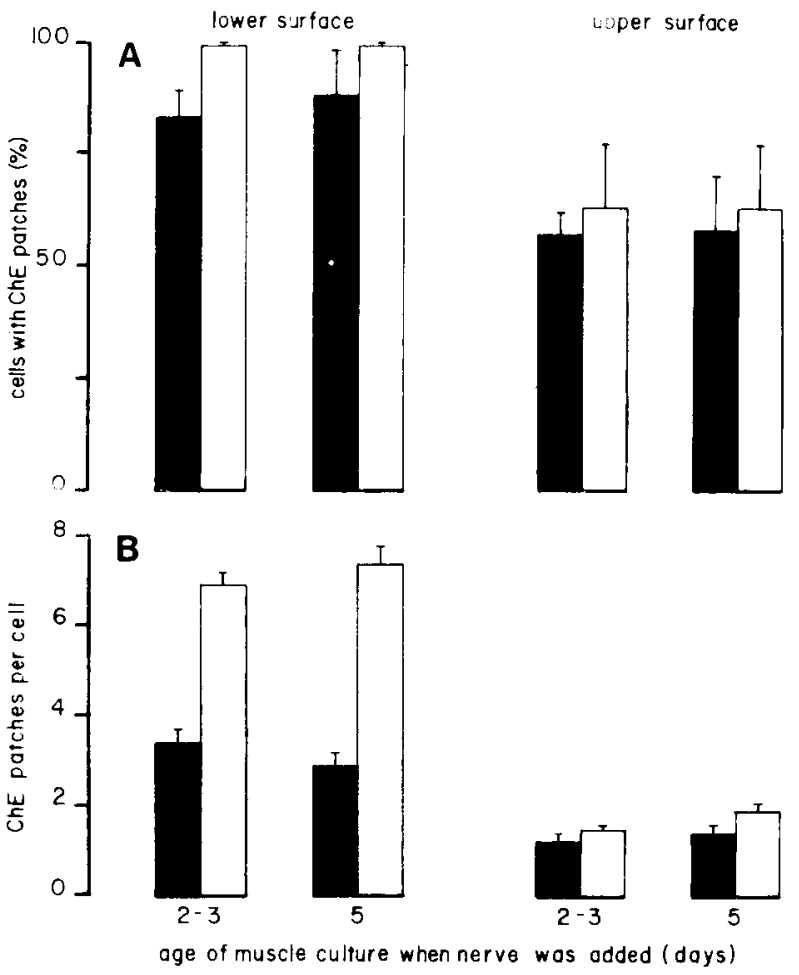

Figure 10. Occurrence of ChE patches on the lower surface and upper surface of nerve-contacted (solid columns) and noncontacted muscle cells (open columns). The nerve-contacted muscle cells had ChE localization along the path of contact. The data are from the same cultures as those in Figure 8. Ninety-one nerve-contacted and 160 noncontacted muscle cells were examined in four cultures in the day 2 to 3 group, and 65 nerve-contacted and 120 noncontacted muscle cells were examined in three cultures in the day 5 group. The bars indicate SE. $A$, Percentage of cells with patches; $B$, number of patches per cell. Note that the number of $\mathrm{ChE}$ patches on the lower surface was substantially reduced on nerve-contacted cells. Because of the high incidence $(>80 \%)$ of co-localization of AChRs and ChE at nerve-muscle contacts, the data in this figure and in Figure 8 remain essentially unchanged whether one considers nerve-contacted muscle cells with AChRs localized at the contact or with $\mathrm{ChE}$ localized at the contact.

For the nerve-contacted muscle cells of Figure 10, $87 \%$ of the nerve contacts occurred exclusively on the edge and/or upper surface of the muscle cells. Therefore, the smaller number of ChE patches on the lower surface cannot be explained by the nerve having contacted preexisting $\mathrm{ChE}$ patches. In addition, just before nerve was added to 5-day muscle cultures, the muscle cells presumably had the same number of $\mathrm{ChE}$ patches on their lower surface as the noncontacted muscle cells which were 4 to 6 days old when examined $(6.9 \pm 0.3$ patches/cell; see first open column in Fig. 10B). Yet 2 to 3 days later, the nerve-contacted muscle cells had significantly fewer $\mathrm{ChE}$ patches on their lower surface $(3.3 \pm 0.3$ patches/cell; see second solid column in Fig. 10B). These findings suggest that contact by an appropriate nerve reduces the survival of pre-existing $\mathrm{ChE}$ patches. However this apparent nerve-induced elimination of $\mathrm{ChE}$ patches is much less complete than the nerve-induced elimination of AChR patches. 


\section{Discussion}

The present study has indicated that many of the AChR patches which develop on embryonic Xenopus muscle cells in culture survive for several days and remain in a fixed position relative to the culture dish. This situation is altered when the muscle cells are contacted by spinal cord neurites. Contact by these neurites not only leads to a local accumulation of AChRs and $\mathrm{ChE}$ at the site of contact but also inhibits the formation of new AChR patches and reduces the survival of pre-existing AChR patches elsewhere on the cell. In addition, the nerve contacts inhibit the formation of ChE patches and appear to cause some reduction in the survival of preexisting ChE patches. That these effects of nerve contact are associated with functional synapse formation is supported by other studies on these cultures in which the localization of AChRs at sites of nerve-muscle contact have been correlated with synaptic function (Anderson et al., 1977, 1979) and with ChE localization and synaptic ultrastructure (Moody-Corbett et al., 1982). Observations on cultures of embryonic chick nerve and muscle have likewise indicated that innervation can terminate the survival of pre-existing AChR patches (Frank and Fischbach, 1979). Innervation in vivo also may prevent the formation and reduce the survival of AChR patches remote from the site of contact (Braithwaite and Harris, 1979; Jacob and Lentz, 1979; Weinberg et al., 1981).

The present findings raise a number of questions. For example, what accounts for the stability of sites of high AChR density; how is the survival of $\mathrm{AChR}$ and $\mathrm{ChE}$ patches terminated; and how are the remote effects of the nerve mediated? Definitive answers are not available to any of these questions, but as described below, existing information does suggest some of the factors which may play a role.

Stability of sites of high AChR density. In the present study, the AChR patches on noncontacted muscle cells often survived for several days as did portions of the AChR accumulations at sites of nerve-muscle contact, even after the nerve retracted. These results may be likened to those obtained at neuromuscular junctions in vivo where, even after denervation, the high $\mathrm{AChR}$ density is maintained for at least several days at immature junctions (Slater, 1978; Lomo and Slater, 1980a) and for many weeks at mature junctions (Hartzell and Fambrough, 1972; Frank et al., 1975; Porter and Barnard, 1975). It may be therefore that common factors contribute to the stability of sites of high AChR density in culture and in vivo. For example, studies on rat myotubes in culture have indicated that the individual receptors within an AChR patch are relatively immobile compared with the receptors which are present at lower density elsewhere on the cell (Axelrod et al., 1976, 1978). AChRs at neuromuscular junctions in mouse (Axelrod et al., 1976) and rat (Fambrough and Pagano, 1977) also have been reported to be relatively immobile. Such findings indicate that $\mathrm{AChRs}$ at sites of high density are physically constrained or anchored and suggest that the constraints or anchors may be necessary for the maintenance of such sites.

That external and internal constraints are present at sites of high AChR density is suggested by a number of studies. For example, the AChR patches which form on the lower surface of cultured muscle cells are not only closely apposed to the surface of the culture dish (Axelrod, 1980, 1981; Bloch and Geiger, 1980) but also are sites of increased adhesion to the culture dish (Moody-Corbett and Cohen, 1979; Bloch and Geiger, 1980). The tightly adhesive links between the cell surface and the culture dish could act to immobilize the AChRs at such sites and thereby contribute to the maintenance of the AChR patch. At the neuromuscular junction, it is the basal lamina material which provides adhesion between the postsynaptic membrane and the nerve terminal, and this extracellular material also contains ChE (Betz and Sakmann, 1971, 1973; Hall and Kelly, 1971; McMahan et al., 1978). Indeed, the synaptic basal lamina of mature muscle has been found to act as a focus for the development of a high density of AChRs (Burden et al., 1979; McMahan et al., 1980a, b). Its action may be related to the fact that it contains filaments which abut on the external surface of the plasma membrane (Ellisman et al., 1976; Heuser, 1980; see also Heuser and Salpeter, 1979). Filaments also abut on the internal surface of the postsynaptic membrane and could act as internal anchors for the AChRs (Ellisman et al., 1976; Heuser, 1980; see also Heuser and Salpeter, 1979). In view of these findings at the neuromuscular junction, it is interesting to note that AChR patches on the lower, as well as upper, surface of Xenopus muscle cells in culture are often sites of ChE localization (Moody-Corbett and Cohen, 1981) and that, at these $\mathrm{ChE}$ sites, the sarcolemma exhibits basal laminalike material on its outer surface and filamentous material on its inner surface (Weldon et al., 1981; see also Weldon and Cohen, 1979). It is therefore attractive to suppose that this extracellular and intracellular material contributes to the maintenance of the sites of high AChR density as suggested for the neuromuscular junction. Recent studies have indicated that specific proteins are localized preferentially at these sites (Bloch and Geiger, 1980; Cartaud et al., 1981; Froehner et al., 1981; Hall et al., 1981). That internal structures play a role in maintaining AChR patches also has been suggested on the basis of experiments in rat myotubes in which the patches were disrupted by metabolic inhibitors (Bloch, 1979). In addition to the presumptive external and internal constraints considered above, evidence has been obtained recently that the cholesterol content of the plasma membrane is reduced at sites of high AChR density in vivo and in culture (Nakajima and Bridgman, 1981; Bridgman and Nakajima, 1981). These findings have raised the possibility that such heterogeneity may contribute to the stability of sites of receptor accumulations.

Even if the AChRs at sites of high density are immobile, at least one other condition must be satisfied for the sites to be maintained. That is, AChRs at these sites must be replaced as fast as they are degraded. At the adult neuromuscular junction, AChRs have been found to have a half-life of several days in contrast to the halflife of about 1 day for extrajunctional AChRs (Berg and Hall, 1974, 1975; Chang and Huang, 1975; Burden, 1977a, b; Linden and Fambrough, 1979) and for AChRs on muscle cells in culture (Devreotes and Fambrough, 1975; Merlie et al., 1976; for review, see Fambrough, 1979). AChRs at immature neuromuscular junctions in vivo 
(Burden, 1977a, b; Reiness and Weinberg, 1981) and at sites of high AChR density on embryonic chick muscle cells in culture (Schuetze et al., 1978) also have a half-life of about 1 day. In these latter cases then, the high AChR density must be maintained by a rapid replacement of the degraded receptors. At present, data are not available concerning the turnover rates of $\mathrm{AChRs}$ on cultured Xenopus muscle cells.

On the basis of the above considerations, there are three main ways by which the maintenance of sites of high AChR density could be terminated. The anchors which keep AChRs at these sites may be removed, the rate at which degraded AChRs are replaced may be reduced, or the degradation rate of the AChRs may be increased. Similar mechanisms also would affect the survival of ChE patches. Recent findings on cultured chick muscle cells have indicated that the degradation rate for ChE is slower than for AChRs (Rotundo and Fambrough, 1980). If this were also the case for Xenopus muscle cells in culture, then an interruption in the supply of AChRs and $\mathrm{ChE}$ would lead to a more rapid disappearance of AChR patches than ChE patches. This could account for our finding that the elimination of ChE patches on nervecontacted muscle cells was much less complete than the elimination of AChR patches.

Role of the nerve in inhibiting the formation and survival of AChR and ChE patches. In causing AChRs and ChE to become localized along the path of contact while at the same time inhibiting the formation and survival of $\mathrm{AChR}$ and $\mathrm{ChE}$ patches elsewhere on the contacted muscle cells, the nerve must induce some spatial reorganization of the cellular components involved in the development and maintenance of sites of AChR and ChE localization. How the nerve exerts such a remarkable influence on the muscle cell is not clear. Our evidence suggests that the effects of the nerve can occur in the absence of muscle contraction and action potentials (see also Anderson and Cohen, 1977; Anderson et al., 1977; Moody-Corbett et al., 1981). Presumably, some other electrical, chemical, or structural modifications associated with nerve-muscle contact play a role. Recent evidence suggests that electrical charge could play a role in these local and remote effects. Positively charged latex beads can induce local accumulation of AChRs at sites of bead-muscle contact and suppress the occurrence of receptor patches elsewhere on the cell (Peng et al., 1981). A similar type of interaction could conceivably mediate the neurally induced effects described in the present study. However, it should be noted that not any nerve can induce these changes. For example, sympathetic and dorsal root ganglion neurites do not induce a local accumulation of AChRs (Cohen and Weldon, 1980; Kidokoro et al., 1980) or synaptic ultrastructure, and such contacted muscle cells still retain receptor patches elsewhere on their surface (Cohen and Weldon, 1980). It is also of interest that, in some cases, the inhibition of AChR patch formation and of AChR patch survival persisted in spite of a relatively brief period of contact between the nerve and muscle (for example, see Figs. 6 and 9). Apparently, the relevant nerve-induced modifications occur even if the contact is transient and are maintained for some time after the contact is termi- nated. Studies on ectopic reinnervation of adult rat muscle likewise have indicated that transient contact can have a continued effect in marking the site where AChRs and ChE become localized (Lomo and Slater, 1980a, b).

The nerve-induced spatial reorganization of cellular components involved in the development and maintenance of sites of AChR and ChE localization may have some bearing on the patterns of innervation that arise under normal and experimental situations. For example, if, upon innervation, the muscle cell's capacity to assemble and maintain postsynaptic membrane were directed entirely to the site of nerve contact, this would necessarily result in a single synaptic site per muscle cell. On the other hand, if the response of the muscle cell did not extend along its full length, then multiple synaptic sites could develop but only at appropriately large intervals. Those intervals would be related to the distance over which the assembly and maintenance of postsynaptic membrane was affected by each set of nerve terminals. Such responses by muscle cells to innervation may account, at least in part, for cases during normal development (Bennett and Pettigrew, 1974, 1975) and during ectopic reinnervation of muscle (Kuffler et al., 1977, 1980; Eldridge et al., 1981) where multiple sites of innervation develop along individual muscle cells and are usually separated from each other by a characteristic minimal distance. The patterns of innervation on neurons (for example, see Sargent and Dennis, 1981) also may be regulated in a similar fashion.

\section{References}

Aitken, J. T. (1950) Growth of nerve implants in voluntary muscle. J. Anat. 84: 38-48.

Anderson, M. J., and M. W. Cohen (1977) Nerve-induced and spontaneous redistribution of acetylcholine receptors on cultured muscle cells. J. Physiol. (Lond.) 268: 757-773.

Anderson, M. J., M. W. Cohen, and E. Zorychta (1977) Effects of innervation on the distribution of acetylcholine receptors on cultured muscle cells. J. Physiol. (Lond.) 268: 731-756.

Anderson, M. J., Y. Kidokoro, and R. Gruener (1979) Correlation between acetylcholine receptor localization and spontaneous synaptic potentials in cultures of nerve and muscle. Brain Res. 166: 185-190.

Antony, M., and D. A. Tonge (1980) Effects of denervation and botulinum toxin on muscle sensitivity to acetylcholine and acceptance of foreign innervation in the frog. J. Physiol. (Lond.) 303: 23-32.

Axelrod, D. (1980) Crosslinkage and visualization of acetylcholine receptors on myotubes with biotinylated $\alpha$-bungarotoxin and fluorescent avidin. Proc. Natl. Acad. Sci. U. S. A. 77: 4823-4827.

Axelrod, D. (1981) Cell-substrate contacts illuminated by total internal reflection fluorescence. J. Cell Biol. 89: 141-145.

Axelrod, D., P. Ravdin, D. E. Koppel, J. Schlessinger, W. W. Webb, E. L. Elson, and T. R. Podleski (1976) Lateral motion of fluorescently labelled acetylcholine receptors in membranes of developing muscle cells. Proc. Natl. Acad. Sci. U. S. A. 73: 4594-4598.

Axelrod, D., P. M. Ravdin, and T. R. Podleski (1978) Control of acetylcholine receptor mobility and distribution in cultured muscle membranes. Biochim. Biophys. Acta 511: 23-38.

Bennett, M. R., and A. G. Pettigrew (1974) The formation of synapses in striated muscle during development. J. Physiol. (Lond.) 241: 515-545.

Bennett, M. R., and A. G. Pettigrew (1975) The formation of 
synapses in amphibian striated muscle during development. J. Physiol. (Lond.) 252: 203-239.

Berg, D. K., and Z. W. Hall (1974) Fate of $\alpha$-bungarotoxin bound to AChRs of normal and denervated muscle. Science 184: 473-475.

Berg, D. K., and Z. W. Hall (1975) Loss of $\alpha$-bungarotoxin from junctional and extrajunctional acetylcholine receptors in rat diaphragm in vivo and in organ culture. J. Physiol. (Lond.) 252: 771-789.

Betz, W., and B. Sakmann (1971) "Disjunction" of frog neuromuscular synapses by treatment with proteolytic enzymes. Nature New Biol. 232: 94-95.

Betz, W. J., and B. Sakmann (1973) Effects of proteolytic enzymes on function and structure of frog neuromuscular junction. J. Physiol. (Lond.) 230: 673-688.

Betz, W. J., J. H. Caldwell, R. R. Ribchester, K. R. Robinson, and R. F. Stump (1980) Endogenous electric field around muscle fibers depends on the $\mathrm{Na}^{+}-\mathrm{K}^{+}$pump. Nature 287: 235237.

Bevan, S., and J. H. Steinbach (1977) The distribution of $\alpha$ bungarotoxin binding sites on mammalian skeletal muscle developing in vivo. J. Physiol. (Lond.) 267: 195-213.

Bloch, R. (1979) Dispersal and reformation of acetylcholine receptor clusters of cultured rat myotubes treated with inhibitors of energy metabolism. J. Cell Biol. 82: 626-643.

Bloch, R. J., and B. Geiger (1980) Localization of acetylcholine receptor clusters in areas of cell-substrate contact in cultures of rat myotubes. Cell 21: 25-35.

Braithwaite, A. W., and A. J. Harris (1979) Neural influence on acetylcholine receptor clusters in embryonic development of skeletal muscle. Nature 279: 549-551.

Brenner, H. R., and B. Sakmann (1978) Gating properties of acetylcholine receptor in newly formed neuromuscular synapses. Nature 271: 366-368.

Bridgman, P. C., and Y. Nakajima (1981) Membrane lipid heterogeneity associated with acetylcholine receptor particle aggregates in Xenopus embryonic muscle cells. Proc. Natl. Acad. Sci. U. S. A. 78: 1278-1282.

Burden, S. (1977a) Development of the neuromuscular junction in the chick embryo: The number, distribution, and stability of acetylcholine receptors. Dev. Biol. 57: 317-329.

Burden, S. (1977b) Acetylcholine receptors at the neuromuscular junction: Developmental change in receptor turnover. Dev. Biol. 61: 79-85.

Burden, S., P. B. Sargent, and U. J. McMahan (1979) Acetylcholine receptors in regenerating muscle accumulate at original synaptic sites in the absence of the nerve. J. Cell Biol. 82: 412-425.

Cartaud, J., A. Sobel, A. Rousselet, P. F. Devaux, and J. P. Changeux (1981) Consequences of alkaline treatment for the ultrastructure of the acetylcholine receptor-rich membranes from Torpedo mamorata electric organ. J. Cell Biol. 90: 418426.

Chang, C. C., and M. C. Huang (1975) Turnover of junctional and extrajunctional acetylcholine receptors of the rat diaphragm. Nature 253: 643-644.

Cohen, M. W., and P. R. Weldon (1980) Localization of acetylcholine receptors and synaptic ultrastructure at nerve-muscle contacts in culture: Dependence on nerve type. J. Cell Biol. 86: $388-401$

Couteaux, R. (1963) The differentiation of synaptic areas. Proc. R. Soc. Lond. (Biol.) 158: 457-480.

Devreotes, P. N., and D. M. Fambrough (1975) Acetylcholine receptor turnover in membranes of developing muscle fibers. J. Cell Biol. 65: 335-358.

Diamond, J., and R. Miledi (1962) A study of foetal and newborn rat muscle fibres. J. Physiol. (Lond.) 162: 393-408.

Eldridge, L., M. Leibhold, and J. H. Steinbach (1981) Altera- tions in cat skeletal neuromuscular junctions following prolonged inactivity. J. Physiol. (Lond.) 313: 529-545.

Ellisman, M. H., J. E. Rash, L. A. Staehlin, and K. R. Porter (1976) Studies of excitable membranes. II. A comparison of specializations at neuromuscular junctions and nonjunctional sarcolemmas of mammalian fast and slow twitch muscle fibers. J. Cell Biol. 68: 752-774.

Elsberg, C. A. (1917) Experiments on motor nerve regeneration and the direct neurotization of paralyzed muscles by their own and by foreign nerves. Science 45: 318-320.

Fambrough, D. M. (1979) Control of acetylcholine receptors in skeletal muscle. Physiol. Rev. 59: 165-227.

Fambrough, D. M., and R. E. Pagano (1977) Positional stability of acetylcholine receptors at the neuromuscular junction. Carnegie Inst. Wash. Year Book 76: 28-29.

Fex, S., B. Sonesson, S. Thesleff, and J. Zelena (1966) Nerve implants in botulinum poisoned mammalian muscle. J. Physiol. (Lond.) 184: 872-882.

Fischbach, G. D., and S. M. Schuetze (1980) A post-natal decrease in acetylcholine channel open time at rat end-plates. J. Physiol. (Lond.) 303: 125-137.

Frank, E., and G. D. Fischbach (1979) Early events in neuromuscular junction formation in vitro. Induction of acetylcholine receptor clusters in the postsynaptic membrane and morphology of newly formed synapses. J. Cell Biol. 83: 143158.

Frank, E., K. Gautvik, and H. Sommerschild (1975) Cholinergic receptors at denervated mammalian motor endplates. Acta Physiol. Scand. 95: 66-76.

Froehner, S. C., V. Gulbrandsen, C. Hyman, A. Y. Jeng, R. R. Neubig, and J. B. Cohen (1981) Immunofluorescence localization at the mammalian neuromuscular junction of the $\mathrm{M}_{\mathrm{r}}$ 43000 protein of Torpedo post-synaptic membranes. Proc. Natl. Acad. Sci. U. S. A. 78: 5230-5234.

Gilliatt, R. W., R. H. Westgaard, and I. K. Williams (1978) Extrajunctional acetylcholine sensitivity of inactive muscle fibres in the baboon during prolonged nerve pressure block. J. Physiol. (Lond.) 280: 499-514.

Hall, Z. W., and R. B. Kelly (1971) Enzymatic detachment of endplate acetylcholinesterase from muscle. Nature New Biol. 232: 62-63.

Hall, Z. W., and C. G. Reiness (1977) Electrical stimulation of denervated muscle reduces incorporation of methionine into the ACh receptor. Nature 268: 655-657.

Hall, Z. W., B. W. Lubit, and J. H. Schwartz (1981) Cytoplasmic actin in postsynaptic structures at the neuromuscular junction. J. Cell Biol. 90: 789-792.

Hartzell, H. C., and D. M. Fambrough (1972) Acetylcholine receptors. Distribution and extrajunctional density in rat diaphragm after denervation correlated with acetylcholine sensitivity. J. Gen. Physiol. 60: 248-262.

Heuser, J. (1980) 3-D visualization of membrane and cytoplasmic specializations at the frog neuromuscular junction. In Ontogenesis and Functional Mechanisms of Peripheral Synapses, J. Taxi, ed., pp. 139-155, Elsevier/North-Holland, Amsterdam.

Heuser, J. E., and S. R. Salpeter (1979) Organization of acetylcholine receptors in quick-frozen, deep-etched, and rotaryreplicated Torpedo post-synaptic membrane. J. Cell Biol. 82: 150-173.

Hogan, P. G., J. M. Marshall, and Z. W. Hall (1976) Muscle activity decreases the rate of degradation of $\alpha$-bungarotoxin bound to extrajunctional acetylcholine receptors. Nature 261 : 328-330.

Jacob, M., and T. L. Lentz (1979) Localization of acetylcholine receptor by means of horseradish peroxidase- $\alpha$-bungarotoxin during formation and development of the neuromuscular junction in the chick embryo. J. Cell Biol. 82: 195-211. 
Jansen, J. K. S., T. Lomo, K. Nicolaysen, and R. H. Westgaard (1973) Hyperinnervation of skeletal muscle fibers: Dependence on muscle activity. Science 181: 559-561.

Karnovsky, M. J. (1964) The loculization of cholinesterase activity in rat cardiac muscle by electron microscopy. J. Cell Biol. 23: 217-232.

Kidokoro, Y., M. J. Anderson, and R. Gruener (1980) Changes in synaptic potential properties during acetylcholine receptor accumulation and neuromuscular interaction in Xenopus nerve-muscle cell culture. Dev. Biol. 74: 490-499.

Kuffler, D. P., W. Thompson, and J. K. S. Jansen (1977) The elimination of synapses in multiply-innervated skeletal muscle fibres of the rat: Dependence on distance between endplates. Brain Res. 138: 353-358.

Kuffler, D. P., W. Thompson, and J. K. S. Jansen (1980) The fate of foreign endplates in cross-innervated rat soleus muscle. Proc. R. Soc. Lond. (Biol.) 208: 189-222.

Kullberg, R. W., P. Brehm, and J. H. Steinbach (1981) Nonjunctional acetylcholine receptor channel open time decreases during development of Xenopus muscle. Nature 289: 411-413.

Linden, D., and D. M. Fambrough (1979) Biosynthesis and degradation of acetylcholine receptors in rat skeletal muscles. Effects of electrical stimulation. Neuroscience 4: 527-538.

Lomo, T., and J. Rosenthal (1972) Control of ACh sensitivity by muscle activity in the rat. J. Physiol. (Lond.) 221: 493513.

Lomo, T., and C. R. Slater (1978) Control of acetylcholine sensitivity and synapse formation by muscle activity. J. Physiol. (Lond.) 275: 391-402.

Lomo, T., and C. R. Slater (1980a) Acetylcholine sensitivity of developing ectopic nerve-muscle junctions in adult rat soleus muscles. J. Physiol. (Lond.) 303: 173-190.

Lomo, T., and C. R. Slater (1980b) Control of junctional acetylcholinesterase by neural and muscular influence in the rat. J. Physiol. (Lond.) 303: 191-202.

MeMahan, U. J., J. R. Sanes, and L. M. Marshall (1978) Cholinesterase is associated with the basal lamina at the neuromuscular junction. Nature 271: 172-174.

McMahan, U. J., D. R. Edgington, and D. P. Kuffler (1980a) Factors that influence regeneration of the neuromuscular junction. J. Exp. Biol. 89: 31-42.

McMahan, U. J., P. B. Sargent, L. L. Rubin, and S. J. Burden (1980b) Factors that influence the organization of acetylcholine receptors in regenerating muscle are associated with the basal lamina at the neuromuscular junction. In Ontogenesis and Functional Mechanisms of Peripheral Synapses, J. Taxi, ed., pp. 345-354, Elsevier/North Holland, Amsterdam.

Merlie, J. -P., J. -P. Changeux, and F. Gros (1976) Acetylcholine receptor degradation measured by pulse chase labelling. $\mathrm{Na}$ ture 264: 74-76.

Miledi, R. (1960) Properties of regenerating neuromuscular synapses in the frog. J. Physiol. (Lond.) 154: 190-205.

Miledi, R. (1962) Induced innervation of end-plate free muscle segments. Nature 193: 281-282.

Moody-Corbett, F., and M. W. Cohen (1979) Development of synaptic specializations on cultured non-innervated muscle cell at sites of contact with the culture dish. Soc. Neurosci. Abstr. 5: 486.

Moody-Corbett, F., and M. W. Cohen (1980) Stability of ACh receptor patches on cultured muscle cells. Can. Fed. Biol. Soc. Proc. 23: 162.
Moody-Corbett, F., and M. W. Cohen (1981) Localization of cholinesterase at sites of high acetylcholine receptor density on embryonic amphibian muscle cells cultured without nerve. J. Neurosci. 1: 596-605.

Moody-Corbett, F., P. R. Weldon, and M. W. Cohen (1982) Cholinesterase localization at sites of nerve contact on embryonic amphibian muscle cells in culture. J. Neurocytol. 11: in press.

Nakajima, Y., and P. C. Bridgman (1981) Absence of filipinsterol complexes from the membranes of active zones and acetylcholine receptor aggregates at frog neuromuscular junctions. J. Cell Biol. 88: 453-458.

Nieuwkoop, P. D., and J. Faber (1967) Normal Table of Xenopus laevis (Daudin), Ed. 2, North-Holland, Amsterdam.

Peng, H. B., P. -C. Cheng, and P. W. Luther (1981) Formation of AChR clusters induced by positively charged latex beads. Nature 292: 831-834.

Porter, C. W., and E. A. Barnard (1975) Distribution and density of cholinergic receptors at the motor endplates of a denervated mouse muscle. Exp. Neurol. 48:542-556.

Reiness, C. G., and C. B. Weinberg (1981) Metabolic stabilization of acetylcholine receptors at newly formed neuromuscular junctions in rat. Dev. Biol. 84: 247-254.

Rotundo, R. L., and D. M. Fambrough (1980) Secretion of acetylcholinesterase: Relation to acetylcholine receptor metabolism. Cell 22: 595-602.

Rubin, L. L., S. M. Schuetze, C. L. Weill, and G. D. Fischbach (1980) Regulation of acetylcholinesterase appearance at neuromuscular junctions in vitro. Nature 28.3: 264-267.

Sakmann, B., and H. R. Brenner (1978) Change in synaptic channel gating during neuromuscular development. Nature 276: 401-402.

Sargent, P. B., and M. J. Dennis (1981) The influence of normal innervation upon abnormal synaptic connections between frog parasympathetic neurons. Dev. Biol. 81: 65-73.

Schuetze, S. M. (1980) The acetylcholine channel time in chick muscle is not decreased following innervation. J. Physiol. (Lond.) 303: 111-124.

Schuetze, S. M., E. F. Frank, and G. D. Fischbach (1978) Channel open time and metabolic stability of synaptic and extrasynaptic acetylcholine receptors on cultured chick myotubes. Proc. Natl. Acad. Sci. U. S. A. 75: 520-523.

Slater, C. R. (1978) Formation and experimental modification of chemical synapses. In Intracellular Functions and Synapses, J. Feldman, N. B. Gilula, and J. D. Pitts, eds., pp. 214239, Chapman and Hall, London.

Steinbach, J. H., J. Merlie, S. Heinemann, and R. Bloch (1979) Degradation of junctional and extrajunctional acetylcholine receptors by developing rat skeletal muscle. Proc. Natl. Acad. Sci. U. S. A. 76: 3547-3551.

Weinberg, C. B., J. R. Sanes, and Z. W. Hall (1981) Formation of neuromuscular junctions in adult rats: Accumulation of acetylcholine receptors, acetylcholinesterase, and components of synaptic basal lamina. Dev. Biol. 84: 255-266.

Weldon, P. R., and M. W. Cohen (1979) Development of synaptic ultrastructure at neuromuscular contacts in an amphibian cell culture system. J. Neurocytol. 8: 239-259.

Weldon, P. R., F. Moody-Corbett, and M. W. Cohen (1981) Ultrastructure of sites of cholinesterase activity on amphibian embryonic muscle cells cultured without nerve. Dev. Biol. 84: 341-350. 